\title{
Evaluation of the Level of Mercury Pollution in the Sediments of the Rivers Draining the Gold Panning Sites in the Territory of Fizi, Eastern Democratic Republic of Congo
}

\author{
Nsambu Mukondwa Pascal1,2,3*, Musibono Eyul'Anki Dieudonné1, Mputu Kanyinda Jean-Noël1 \\ ${ }^{1}$ Department of Environmental Sciences, Faculty of Sciences, Doctoral Cycle, University of Kinshasa, D. R. of Congo \\ ${ }^{2}$ Faculty of Agricultural Sciences and Environment, Evangelical University in Africa, Bukavu, D. R. of Congo \\ ${ }^{3}$ General Agronomy Section, High Institute of Agronomic and Veterinary Studies of Mushweshwe, Bukavu, D. R. of Congo \\ Email: *nsambumukonduasumu@gmail.com
}

How to cite this paper: Pascal, N. M., Dieudonné, M. E., \& Jean-Noël, M. K. (2020). Evaluation of the Level of Mercury Pollution in the Sediments of the Rivers Draining the Gold Panning Sites in the Territory of Fizi, Eastern Democratic Republic of Congo. Journal of Geoscience and Environment Protection, 8, 97-111.

https://doi.org/10.4236/gep.2020.82007

Received: December 24, 2019

Accepted: February 14, 2020

Published: February 17, 2020

Copyright $\odot 2020$ by author(s) and Scientific Research Publishing Inc. This work is licensed under the Creative Commons Attribution International License (CC BY 4.0).

http://creativecommons.org/licenses/by/4.0/

\begin{abstract}
The sediments collected respectively from the Etó, Kacumvi, Kimbi, Lubichako, Makungu, Kuwa, Mandje, Misisi and Kimuti Rivers draining the gold panning sites in the Fizi territory were studied during a 16-month cycle (August and December 2016 to August and December 2017) in order to assess their degree of mercury pollution in the dry season as well as in the rainy season. The assessment of the degree of pollution of the said sediments focused on six parameters including the total mercury content $(\mathrm{THg})$ and the indices of mercury pollution such as the mercury enrichment factor (EF), the mercury contamination factor $(\mathrm{CF})$, the mercury geoaccumulation index $\left(\mathrm{I}_{\text {geo }}\right)$, the mercury potential ecological risk factor (PERF) and the mercury ecological risk index (ERI). Total mercury was determined by atomic absorption spectrophotometry (AAS) while the mercury pollution indices were successively calculated using the appropriate formulas. The results thus obtained revealed that all the sediments of the rivers studied are considerably polluted by mercury according to the values relative to their total mercury content and mercury pollution indices, including the mercury enrichment factor (EF), the mercury contamination factor $(\mathrm{CF})$, the mercury geoaccumulation index $\left(\mathrm{I}_{\text {geo }}\right)$, the mercury potential ecological risk factor (PERF) and the mercury ecological risk index (ERI), which greatly exceed the standards recommended by the Canadian Council of Ministers of the Environment. In particular, the sediments of the Kimbi River are highly polluted by mercury compared to those of other rivers studied. This reported pollution is the result of anthropogenic gold panning activities that generate effluents and elemental mercury that pollute the streams.
\end{abstract}




\section{Keywords}

Mercurial Pollution, Territory of Fizi, Sediments, Sites, Rivers, Gold Panning, DRC

\section{Introduction}

Almost the entire surface of planet earth is covered by aquatic ecosystems. In recent decades, these aquatic ecosystems have been seriously threatened by pollution, often of anthropogenic origin. In fact, effluents containing chemical pollutants from artisanal and industrial activities (iron and steel industry, metallurgy, tannery, etc.) are discharged into all environmental compartments, particularly in aquatic environments (Pestana et al., 2010).

Mercury is an integral part of the major metallic pollutants commonly found in aquatic ecosystems. This toxic global pollutant can enter watercourses either by surface runoff and/or directly from locally polluted wastewater or by wet atmospheric deposition. It has proven toxicity even at low levels, as do other trace metallic elements such as lead and cadmium (Wang et al., 2009).

In the aquatic environment, mercury and other trace metal elements (TMEs) accumulate in sediments to the point where they become reservoirs for contaminants. As a result of physical, biological or chemical transformations, sediments can also be a significant source of mercury for the water column, benthic organisms, fish, etc. (Tessier, 2012).

Contaminants stored in sediment in this way can continue to disrupt the aquatic ecosystem, even after measures are taken to stop or regulate their inputs. It is therefore necessary to determine the mercury content in sediments, which constitute a "memory" of the life of the river, including episodes of pollution (Kennish, 2002).

Nowadays, studies relating to the assessment of mercury pollution levels in river sediments occupy the hearts of many researchers. Some of them have reported that the sediments of the Toulon roadstead are polluted by mercury (Tessier, 2012), the sediments of the Porto-Novo lagoon (South Benin) are heavily polluted by the mercury contained in the effluents that are regularly discharged there (Chouti et al., 2010), the mercury content is worrying in the sediments of the Tambopata, Malinowski and Heath rivers draining the Peruvian artisanal gold mining sites, etc. (Gerardo et al., 2018).

At present, there is no information on the level of mercury pollution in the sediments of the rivers draining the gold panning sites in the province of South Kivu in general and those in the territory of Fizi in particular. However, the quality of the sediments in the rivers of the gold panning sites in the territory of Fizi is said to be deteriorating, all the more so as, in this region, the effluents resulting from artisanal gold mining are discharged into the rivers without having been recycled in advance and the gold-mercury amalgam is generally incinerated 
in the open air on the said sites. Thus, this study aims to fill the above-mentioned gaps. Its main purpose is to evaluate the degree of mercury pollution in the sediments of the rivers draining the gold panning sites in the Fizi territory using the total mercury content and the indices of mercury pollution, including the mercury enrichment factor (EF), the mercury contamination factor (CF), the mercury geoaccumulation index $\left(\mathrm{I}_{\text {geo }}\right)$, the mercury potential ecological risk factor (PERF) and the mercury ecological risk index (ERI).

\section{Material and Methods}

\subsection{Study Area}

This study focused on sediments taken from rivers (Kimbi, Mandje, Misisi, Kimuti, Kacumvi, Kuwa, Lubichako, Etó and Makungu) that drain artisanal gold mining sites in the Fizi territory. This territory is part of the eight territories that make up the province of South Kivu in the east of the Democratic Republic of Congo (DRC). Geographically, the territory of Fizi is located between $3^{\circ} 30^{\prime}$ and $4^{\circ} 51^{\prime} 32^{\prime \prime}$ South latitude, $27^{\circ} 45^{\prime}$ and $29^{\circ} 14^{\prime} 10^{\prime \prime}$ East longitude. It is bounded to the north by the territory of Uvira, to the west by the territory of Mwenga and Shabunda, to the south by the territory of Kalemie (Tanganyika), and to the east by Lake Tanganyika (Munyaas, 2016). The geographical coordinates of different points of the sediment samples along the rivers were taken by GPS/GARMIN to an error of about 8 - 9 meters. In addition, the map containing the different points of the sediment samples studied was drawn by Arc GIS 10.3 software. Information related to the location of different points of sediment sampling along the studied rivers is highlighted in Figure 1.

\subsection{Methods of Sampling and Analysis of Sediment Samples}

Samples of the studied sediments were collected during 4 Campaigns (August 2016, December 2016, August 2017 and December 2017) in order to assess the seasonal variability of their mercury pollution levels. These samples were taken at strategic sampling points along the rivers: upstream of the discharge point (control or reference sites), immediately downstream of the effluent discharge site.

The sampling in question took place between 9:00 and 10:00 for all target locations but on different days in order to minimize the risk of daily variability and to take into account as much as possible the timing of the largest releases. It should be noted that these sediment samples were taken $0.5 \mathrm{~m}$ from the bays by driving the PVC core barrel into the river. This sampling operation was repeated twice and the samples were mixed to form a composite sample to reduce the variation in results and the uncertainty surrounding the mean value obtained in the laboratory analysis of the parameters sought.

The resulting composite sediment core was packaged in a clean, pre-labeled $500 \mathrm{~mL}$ plastic box. All boxes containing the composite sediment core were stored in situ at $4^{\circ} \mathrm{C}$ in coolers before being sent to the laboratory for analysis. 


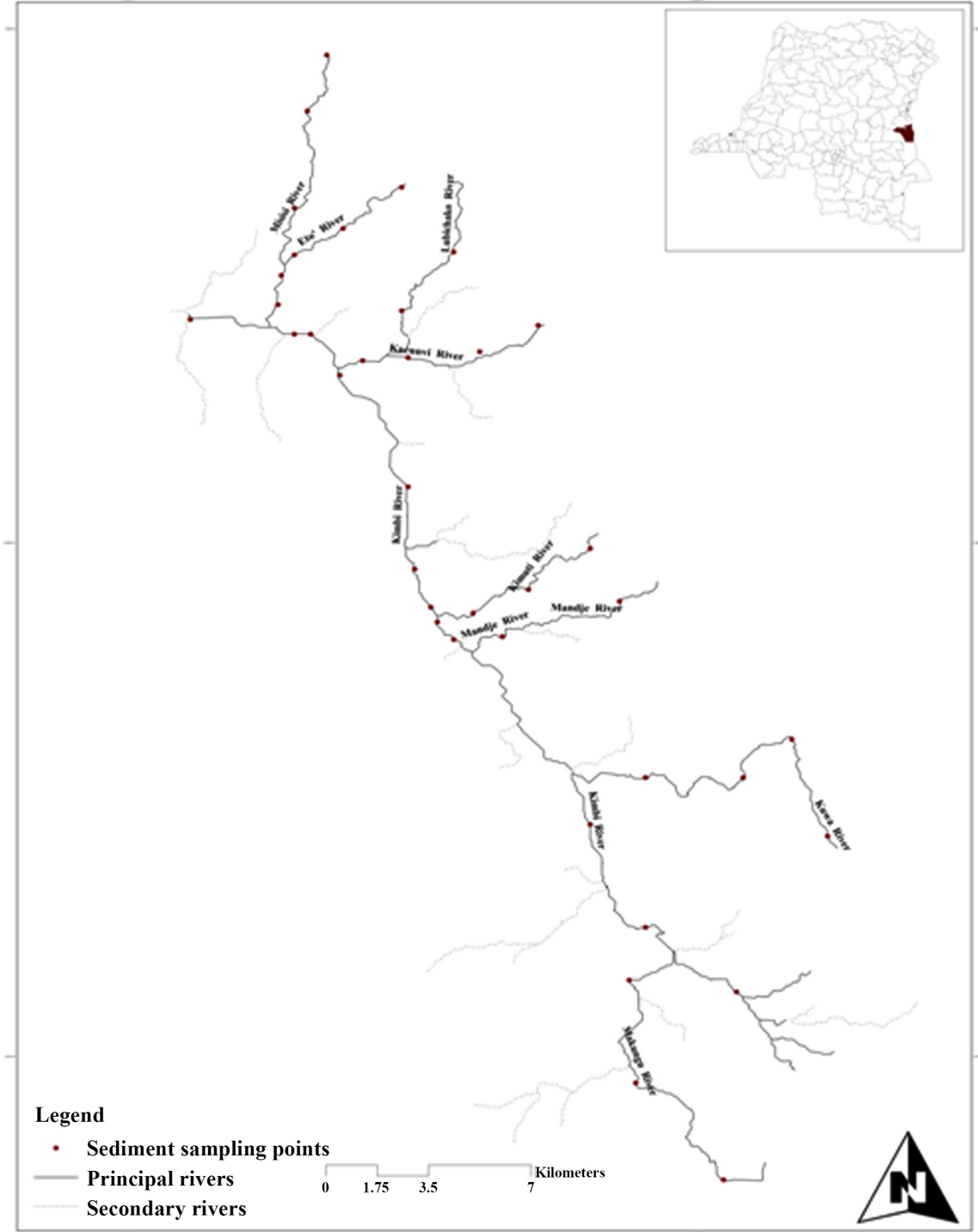

Figure 1. Map of location of sediment sampling sites.

Six variables were measured to assess the degree of mercury pollution in sediments collected from the rivers studied, including total mercury content and mercury pollution or contamination indices such as the mercury enrichment factor, the mercury contamination factor, the mercury geoaccumulation index, the mercury potential ecological risk factor and the mercury ecological risk index. Total mercury was determined according to standard analytical methods using the Atomic Absorption Spectrophotometer (AAS) (AA500). Mercury standard solutions were prepared in advance to determine the mercury content in different sediment samples. These solutions were kept in clean plastic bottles that were pre-washed with concentrated nitric acid and distilled water. In addition, the enrichment factor was calculated using the following formula:

$$
\mathrm{EF}=\frac{[\mathrm{Me}]_{\mathrm{mes}} /[\mathrm{Al}]_{\mathrm{mes}}}{[\mathrm{Me}]_{\mathrm{Th}} /[\mathrm{Al}]_{\mathrm{Th}}}
$$


where, $[\mathrm{Me}]_{\text {mes }}=$ The concentration of the analyte (Hg in this case) in the sediment sample collected from sites subject to anthropogenic activities.

$[\mathrm{Al}]_{\mathrm{mes}}=$ The concentration of aluminum in the sediment sample collected from sites subject to anthropogenic activities.

$[\mathrm{Me}]_{\mathrm{Th}}=$ The concentration of the analyte (Hg in this case) in the soil sample from the reference site, natural site or site with no anthropogenic activities. This is the reference concentration of the analyte ( $\mathrm{Hg}$ in this case). This is generally referred to as the natural background level.

$[\mathrm{Al}]_{\mathrm{Th}}=$ The concentration of aluminum in the soil sample from the reference site, natural site or no human activity site.

For the case of the present study, the reference site chosen is indeed the field of the village of Lulimba where no gold panning activity is carried out. Hence, total mercury and aluminum concentrations in topsoil from this field were considered as reference concentrations to determine the mercury enrichment factor in all river sediment samples from the artisanal gold mining sites in Fizi.

In addition, it should be pointed out that the element aluminum has been used for geochemical standardization as usual for the following reasons: aluminum, generally measured, is poorly soluble and so far unaffected by pollution.

Moreover, this is generally considered to be conservative. Thus, the pollution intensity scale based on the values of the enrichment factor (EF) intervals has five classes below: $\mathrm{EF} \leq 2$ (No or low anthropogenic enrichment); $2<\mathrm{EF}<5$ (Moderate enrichment); $5<\mathrm{EF}<20$ (Significant enrichment); $20<\mathrm{EF}<40$ (Very high enrichment) and $\mathrm{EF} \geq 40$ (Extreme enrichment) (Poulton \& Raiswel, 2000).

The geoaccumulation index was calculated using the following formula proposed by Müller in 1979:

$$
\mathrm{I}_{\text {geo }}=\log _{2}\left(\frac{[\mathrm{Me}]_{\mathrm{mes}}}{[\mathrm{Me}]_{\mathrm{Th}}} \times 1.5\right)
$$

The coefficient 1.5 is a correction factor that takes into account natural fluctuations in the grade of a given metal that can be attributed to mineralogical changes in the sediment. This geoaccumulation index is associated with a pollution scale of seven classes below: $\mathrm{I}_{\text {geo }} \leq 0$ (Unpolluted sediments or soils or Background); $0<\mathrm{I}_{\text {geo }}<1$ (Unpolluted to moderately polluted sediments); $1<\mathrm{I}_{\text {geo }}<2$ (Moderately polluted sediments); $2<\mathrm{I}_{\text {geo }}<3$ (Moderately to heavily polluted sediments); $3<\mathrm{I}_{\text {geo }}<4$ (Heavily polluted sediments); $4<\mathrm{I}_{\text {geo }}<5$ (Heavily to extremely polluted sediments); $\mathrm{I}_{\text {geo }}>5$ (Extremely polluted sediments) (Manjunatha et al., 2001).

The contamination factor for mercury was determined by the following relationship:

$$
\mathrm{CF}=\frac{\mathrm{C}_{\mathrm{Hg}}}{\mathrm{B}_{\mathrm{Hg}}}
$$

with, $\mathrm{CF}=$ Mercury contamination factor; $\mathrm{C}_{\mathrm{Hg}}=$ Mercury concentration in se- 
diment samples from anthropogenic sites; $\mathrm{B}_{\mathrm{Hg}}=$ Mercury concentration in the soil sample of the reference site, natural site or site without possible anthropogenic activities (soil of the village of Lulimba). It is the reference concentration of this metallic element. The mercury contamination factor is related to a pollution scale of four classes as follows: $\mathrm{CF}<1$ (no or no contamination/pollution); $1 \leq$ $\mathrm{CF}<3$ (moderate contamination/pollution); $3 \leq \mathrm{CF}<6$ (considerable contamination/pollution); $6 \leq \mathrm{CF}$ (very high contamination/pollution) (Banu et al., 2013).

The Ecological Potential Risk Factor was determined by multiplying the mercury toxic response factor values by the mercury contamination factor values. Hence the following notation:

$$
\mathrm{EPRF}=\mathrm{Tf}_{\mathrm{Hg}} \times \mathrm{CF} \quad \text { (Banu et al., 2013). }
$$

where $\mathrm{Tf}_{\mathrm{Hg}}=$ Mercury toxic response factor $=40 ; \mathrm{CF}=$ Mercury contamination factor. It should be noted that the potential ecological risk factor of mercury is related to a pollution scale of the following five classes: EPRF $<40$ (contamination/pollution with low ecological risk potential); $40 \leq \mathrm{EPRF}<80$ (contamination/pollution with moderate ecological risk potential); $80 \leq \mathrm{EPRF}<160$ (contamination/pollution with considerable ecological risk potential); $160 \leq \mathrm{EPRF}<$ 320 (contamination/pollution with high ecological risk potential); EPRF $>320$ (contamination/pollution with very high ecological risk potential) (Bhuiyan et al., 2010).

Finally, the Ecological Risk Index for mercury was determined by summing the values of the potential ecological risk factors for this metallic element (Banerjee et al., 2016). Hence the following relationship:

$$
\mathrm{ERI}=\sum_{i=1}^{n} \mathrm{EPRFi}
$$

The ecological risk index for mercury is aggregated on a pollution scale of four classes as follows: ERI $<150$ (contamination/pollution of low ecological risk); $150 \leq \mathrm{ERI}<300$ (contamination/pollution of moderate ecological risk); $300 \leq$ ERI $<600$ (contamination/pollution of considerable ecological risk); ERI $\geq 600$ (contamination/pollution of very high ecological risk) (Bhuiyan et al., 2010).

\subsection{Statistical Treatment of Data}

The results obtained have been encoded and processed by Microsoft Excel 2010. The software $\mathrm{R}$ version 2.15.1 was used for the descriptive analyses of these results while XLSTAT 2016 was used to separate the means of different factors at the $5 \%$ significance level.

\section{Results and Discussion}

\subsection{Total Mercury Levels in the Sediments Studied}

Results for total mercury levels in various sediments studied are presented in Table 1 . 
Table 1. Total mercury concentrations.

\begin{tabular}{|c|c|c|c|c|c|c|c|c|c|c|}
\hline $\begin{array}{c}\text { Rivers/ } \\
\text { Campaigns } \\
\text { and Parameter }\end{array}$ & Etó & Kacumvi & Kimbi & Kimuti & Kuwa & Lubichako & Makungu & Mandje & Misisi & Mean \\
\hline $\mathrm{T}_{\mathrm{Hg}}(\mathrm{mg} / \mathrm{Kg})$ & \multicolumn{5}{|c|}{$P$-value for the Rivers: 0.000} & \multicolumn{4}{|c|}{ P-value for the Campaigns: 0.743} & \\
\hline Campaign 1 & $\begin{array}{c}32.258 \pm \\
0.025\end{array}$ & $\begin{array}{c}24.211 \pm \\
0.032\end{array}$ & $\begin{array}{c}85.868 \pm \\
0.811\end{array}$ & $\begin{array}{c}12.997 \pm \\
0.124\end{array}$ & $\begin{array}{c}19.112 \pm \\
0.421\end{array}$ & $\begin{array}{c}28.769 \pm \\
0.013\end{array}$ & $\begin{array}{c}35.277 \pm \\
0.310\end{array}$ & $\begin{array}{c}16.337 \pm \\
0.513\end{array}$ & $\begin{array}{c}40.159 \pm \\
0.211\end{array}$ & $\begin{array}{c}32.776 \pm \\
0.273\end{array}$ \\
\hline Campaign 2 & $\begin{array}{c}33.228 \pm \\
0.029\end{array}$ & $\begin{array}{c}24.939 \pm \\
0.314\end{array}$ & $\begin{array}{c}88.445 \pm \\
0.872\end{array}$ & $\begin{array}{c}13.386 \pm \\
0.204\end{array}$ & $\begin{array}{c}19.686 \pm \\
0.439\end{array}$ & $\begin{array}{c}29.632 \pm \\
0.120\end{array}$ & $\begin{array}{c}36.337 \pm \\
0.312\end{array}$ & $\begin{array}{c}16.825 \pm \\
0.521\end{array}$ & $\begin{array}{c}41.295 \pm \\
0.236\end{array}$ & $\begin{array}{c}33.753 \pm \\
0.339\end{array}$ \\
\hline Campaign 3 & $\begin{array}{c}34.224 \pm \\
0.100\end{array}$ & $\begin{array}{c}25.688 \pm \\
0.411\end{array}$ & $\begin{array}{c}91.098 \pm \\
0.821\end{array}$ & $\begin{array}{c}13.786 \pm \\
0.312\end{array}$ & $\begin{array}{c}20.276 \pm \\
0.468\end{array}$ & $\begin{array}{c}30.521 \pm \\
0.127\end{array}$ & $\begin{array}{c}37.426 \pm \\
0.415\end{array}$ & $\begin{array}{c}17.332 \pm \\
0.523\end{array}$ & $\begin{array}{c}42.524 \pm \\
0.342\end{array}$ & $\begin{array}{c}34.764 \pm \\
0.391\end{array}$ \\
\hline Campaign 4 & $\begin{array}{c}35.251 \pm \\
0.210\end{array}$ & $\begin{array}{c}26.460 \pm \\
0.424\end{array}$ & $\begin{array}{c}93.832 \pm \\
0.898\end{array}$ & $\begin{array}{c}14.198 \pm \\
0.365\end{array}$ & $\begin{array}{c}20.883 \pm \\
0.512\end{array}$ & $\begin{array}{c}31.438 \pm \\
0.211\end{array}$ & $\begin{array}{c}38.549 \pm \\
0.452\end{array}$ & $\begin{array}{c}17.852 \pm \\
0.536\end{array}$ & $\begin{array}{c}43.800 \pm \\
0.453\end{array}$ & $\begin{array}{c}35.807 \pm \\
0.451\end{array}$ \\
\hline Mean & $\begin{array}{c}33.740 \pm \\
0.091^{\mathrm{d}}\end{array}$ & $\begin{array}{c}25.324 \pm \\
0.295^{\mathrm{f}}\end{array}$ & $\begin{array}{c}89.811 \pm \\
0.851^{\mathrm{a}}\end{array}$ & $\begin{array}{c}13.591 \pm \\
0.251^{\mathrm{h}}\end{array}$ & $\begin{array}{c}19.989 \pm \\
0.460^{\mathrm{g}}\end{array}$ & $\begin{array}{c}30.090 \pm \\
0.118^{\mathrm{e}}\end{array}$ & $\begin{array}{c}36.897 \pm \\
0.372^{\mathrm{c}}\end{array}$ & $\begin{array}{c}17.086 \pm \\
0.523^{\mathrm{g}}\end{array}$ & $\begin{array}{c}41.945 \pm \\
0.311^{\mathrm{b}}\end{array}$ & $\begin{array}{c}34.275 \pm \\
0.364\end{array}$ \\
\hline
\end{tabular}

Means with the same letters in the row or column are not statically different at significance level alpha = 0.05; Campaign 1: August 2016; Campaign 2: December 2016; Campaign 3: August 2016; Campaign 4: December 2017; $\mathrm{T}_{\mathrm{Hg}}=$ Total mercury content.

The results presented in Table 1 show that the mean values of total mercury levels in the sediments of all the rivers of the gold panning sites in the Fizi territory were of the order of $34.275 \pm 0.364 \mathrm{mg} / \mathrm{Kg}$. However, all of the sediments collected from the rivers studied were found to be contaminated with mercury because their total mercury concentrations significantly exceeded the sediment quality standards that require tolerable levels of total mercury in sediment to be no more than $0.4 \mathrm{mg} / \mathrm{Kg}$. In addition, it was found that total mercury concentrations in the sediments of all the rivers studied did not vary significantly between study Campaigns ( $\mathrm{P}$-value $=0.743$ ) although they did vary highly significantly from river to river $(\mathrm{P}$-value $=0.000)$. In fact, sediments from the Kimbi River had the highest mean total mercury levels compared to sediments from other rivers $(89.811 \pm 0.851 \mathrm{mg} / \mathrm{Kg})$, followed alternately by sediments from the Misisi River $(41.945 \pm 0.311 \mathrm{mg} / \mathrm{Kg})$; Makungu River $(36.897 \pm 0.372 \mathrm{mg} / \mathrm{Kg}$ ); Etó (33.740 $\pm 0.091 \mathrm{mg} / \mathrm{Kg})$; Lubichako (30.090 $\pm 0.118 \mathrm{mg} / \mathrm{Kg})$; Kacumvi (25.324 \pm $0.295 \mathrm{mg} / \mathrm{Kg})$; then Kuwa $(19.989 \pm 0.460 \mathrm{mg} / \mathrm{Kg})$ and Mandje $(17.086 \pm 0.523$ $\mathrm{mg} / \mathrm{Kg}$ ) with statistically identical mean concentrations of total mercury; and Kimuti $(13.591 \mathrm{mg} / \mathrm{Kg})$. These results are in agreement with those of Chouti et al. (2010); Noah \& Anthony (2016); Marie (2012) and Delphine (2002) which stipulate successively that the levels of total mercury in the sediments of the Ankobra and Tano rivers (Ghana), those of the Porto-Novo lagoon (South Benin) as well as the marine, estuarine and coastal sediments of the Seine (France) and the Bay of Kaštela (Croatia) have largely exceeded acceptable limits.

\subsection{Mercury Enrichment Factor for the Sediments Studied}

Results that are consistent with the mercury enrichment factors in the sediments studied are presented in Table 2. 
Table 2. Mercury enrichment factor for the sediments studied.

\begin{tabular}{|c|c|c|c|c|c|c|c|c|c|c|}
\hline $\begin{array}{c}\text { Rivers/ } \\
\text { Campaigns and } \\
\text { Parameter }\end{array}$ & Etó & Kacumvi & Kimbi & Kimuti & Kuwa & Lubichako & Makungu & Mandje & Misisi & Mean \\
\hline $\mathrm{EF}$ & & \multicolumn{3}{|c|}{ P-value for the Campaigns: 0.000} & \multicolumn{4}{|c|}{ P-value for the Rivers: 0.000} & & \\
\hline Campaign 1 & $\begin{array}{c}11.204 \pm \\
0.019\end{array}$ & $\begin{array}{c}7.308 \pm \\
0.300\end{array}$ & $\begin{array}{c}17.197 \pm \\
0.009\end{array}$ & $\begin{array}{c}5.816 \pm \\
0.360\end{array}$ & $\begin{array}{c}8.209 \pm \\
0.034\end{array}$ & $\begin{array}{c}10.352 \pm \\
0.089\end{array}$ & $\begin{array}{c}12.287 \pm \\
0.712\end{array}$ & $\begin{array}{c}7.028 \pm \\
0.171\end{array}$ & $\begin{array}{c}10.615 \pm \\
0.086\end{array}$ & $\begin{array}{r}10.002 \pm \\
0.198^{\mathrm{d}}\end{array}$ \\
\hline Campaign 2 & $\begin{array}{c}12.188 \pm \\
0.118\end{array}$ & $\begin{array}{c}11.023 \pm \\
0.312\end{array}$ & $\begin{array}{c}19.389 \pm \\
0.105\end{array}$ & $\begin{array}{c}6.867 \pm \\
0.314\end{array}$ & $\begin{array}{c}10.222 \pm \\
0.022\end{array}$ & $\begin{array}{c}11.264 \pm \\
0.124\end{array}$ & $\begin{array}{c}14.414 \pm \\
0.741\end{array}$ & $\begin{array}{c}8.298 \pm \\
0.179\end{array}$ & $\begin{array}{c}14.133 \pm \\
0.182\end{array}$ & $\begin{array}{r}11.978 \pm \\
0.233^{\mathrm{c}}\end{array}$ \\
\hline Campaign 3 & $\begin{array}{c}24.690 \pm \\
0.919\end{array}$ & $\begin{array}{c}23.407 \pm \\
0.362\end{array}$ & $\begin{array}{c}36.932 \pm \\
0.214\end{array}$ & $\begin{array}{c}21.923 \pm \\
0.369\end{array}$ & $\begin{array}{c}22.498 \pm \\
0.120\end{array}$ & $\begin{array}{c}23.063 \pm \\
0.081\end{array}$ & $\begin{array}{c}26.390 \pm \\
0.749\end{array}$ & $\begin{array}{c}22.333 \pm \\
0.017\end{array}$ & $\begin{array}{c}29.255 \pm \\
0.214\end{array}$ & $\begin{array}{r}25.610 \pm \\
0.338^{\mathrm{b}}\end{array}$ \\
\hline Campaign 4 & $\begin{array}{c}48.977 \pm \\
0.891\end{array}$ & $\begin{array}{c}43.681 \pm \\
0.134\end{array}$ & $\begin{array}{c}78.293 \pm \\
0.142\end{array}$ & $\begin{array}{c}43.523 \pm \\
0.342\end{array}$ & $\begin{array}{c}44.973 \pm \\
0.142\end{array}$ & $\begin{array}{c}45.303 \pm \\
0.812\end{array}$ & $\begin{array}{c}52.223 \pm \\
0.071\end{array}$ & $\begin{array}{c}44.853 \pm \\
0.021\end{array}$ & $\begin{array}{c}53.483 \pm \\
0.081\end{array}$ & $\begin{array}{r}50.590 \pm \\
0.293^{\mathrm{a}}\end{array}$ \\
\hline Mean & $\begin{array}{c}24.265 \pm \\
0.487^{\mathrm{c}}\end{array}$ & $\begin{array}{c}21.355 \pm \\
0.277^{\mathrm{d}}\end{array}$ & $\begin{array}{c}37.953 \pm \\
0.118^{\mathrm{a}}\end{array}$ & $\begin{array}{c}19.532 \pm \\
0.346^{\mathrm{f}}\end{array}$ & $\begin{array}{c}21.476 \pm \\
0.080^{\mathrm{d}}\end{array}$ & $\begin{array}{c}22.496 \pm \\
0.276^{c}\end{array}$ & $\begin{array}{c}26.329 \pm \\
0.568^{\mathrm{b}}\end{array}$ & $\begin{array}{c}20.628 \pm \\
0.097^{\mathrm{e}}\end{array}$ & $\begin{array}{c}26.872 \pm \\
0.141^{\mathrm{b}}\end{array}$ & $\begin{array}{c}24.545 \pm \\
0.266\end{array}$ \\
\hline
\end{tabular}

Means with the same letters in the row or column are not statically different at significance level alpha = 0.05; Campaign 1: August 2016; Campaign 2: December 2016; Campaign 3: August 2016; Campaign 4: December 2017; EF = Enrichment factor.

The results shown in Table 2 show that the mean value of mercury enrichment factors in the sediments of all these rivers was of the order of $24.545 \pm$ 0.266. However, these mercury enrichment factors in the sediments of the rivers studied were found to vary highly significantly from one river to another (P-value $=0.000$ ). In fact, the Kimbi River sediments had the highest mean mercury enrichment factor value compared to the mean values of mercury enrichment factors in the sediments of other rivers $(37.953 \pm 0.118)$, followed alternately by the sediments of the Misisi $(26.872 \pm 0.141)$ and Makungu (26.329 \pm 0.568$)$ Rivers, whose mean values of mercury enrichment factors are statistically identical; then Etó $(24.265 \pm 0.487)$ and Lubichako (22.496 \pm 0.276$)$ whose mean values of mercury enrichment factors are statistically similar; then Kuwa $(21.476 \pm 0.080)$ and Kacumvi (21.355 \pm 0.277$)$ whose mean values of mercury enrichment factors are statistically similar; Mandje (20.628 \pm 0.097$)$; and finally Kimuti (19.532 $\pm 0.346)$. In terms of the intensity of mercury pollution in the sediments of these rivers, it has been noted that anthropogenic mercury enrichment has been very high in the sediments of the Kimbi, Misisi, Makungu, Etó, Lubichako, Kacumvi, Kuwa and Mandje rivers, respectively $(20<\mathrm{EF}<40)$; significant in the sediments of the Kimuti River. Similarly, the mean values of mercury enrichment factors in the sediments of the rivers studied also varied in a highly significant way from one investigation Campaign to another $(\mathrm{P}$-value $=0.000)$ while increasing considerably from Campaign 1 (August 2016) to Campaign 4 (December 2017). Thus, Campaign 4 (December 2017) presented the highest average values of mercury enrichment factors for all the rivers studied $(57.307 \pm 0.293)$ followed successively by Campaign 3 (August 2017) for which the average values of mercury enrichment factors were of the order of $28.488 \pm 0.338$; Campaign 2 (December 2016) for which the average values of the mercury enrichment factors were equal 
to $13.897 \pm 0.233$ and finally campaign 1 (August 2016) for which the average values of the mercury enrichment factors were of the order of $11.769 \pm 0.198$. Based on the mercury enrichment factor, Niane (2014) had also found that anthropogenic mercury enrichment was very high in the sediments of the Gambia River, which drains gold mining sites in the Kédougou region (eastern Senegal). In addition to this, it also found that mercury enrichment factors in the sediments of the Gambia River varied very significantly between campaigns (January 2011 and November 2011).

\subsection{Mercury Geoaccumulation Index for the Sediments Studied}

Results that are consistent with the mercury geoaccumulation index are shown in Table 3.

Based on the results in Table 3, it appears that the mean values of the mercury geoacumulation index in the sediments of the rivers studied were $4.771 \pm 0.384$. Moreover, these values varied highly significantly from one river to another $(\mathrm{P}$-value $=0.000)$. In fact, Kimbi River sediments had the highest mean mercury geoaccumulation index $\left(\mathrm{I}_{\text {geo }}\right)$ value relative to the mean mercury geoaccumulation index values of sediments from other rivers $(6.719 \pm 0.711)$, followed alternately by Misisi River sediments $(4.826 \pm 0.192)$, Makungu (4.771 \pm 0.201$)$, Etó $(4.625 \pm 0.101)$, Lubichako (4.507 \pm 0.604), Kacumvi (4.456 \pm 0.685$)$, Kuwa (4.445 \pm 0.389$)$, Mandje (4.414 \pm 0.224$)$ and Kimuti (4.172 \pm 0.346$)$ with statistically similar mean mercury geoaccumulation index values. With regard to the intensity of mercury pollution of the sediments of the above-mentioned rivers, it was necessary to point out that the sediments of the Kimbi River were extremely polluted with mercury because the average value of their mercury geoaccumulation index was higher than $5\left(\mathrm{I}_{\text {geo }}>5\right)$. On the other hand, the sediments of the

Table 3. Mercury geoaccumulation index for the sediments studied.

\begin{tabular}{|c|c|c|c|c|c|c|c|c|c|c|}
\hline $\begin{array}{c}\text { Rivers/ } \\
\text { Campaigns and } \\
\text { Parameter }\end{array}$ & Etó & Kacumvi & Kimbi & Kimuti & Kuwa & Lubichako & Makungu & Mandje & Misisi & Mean \\
\hline $\mathrm{I}_{\text {geo }}$ & \multicolumn{4}{|c|}{ P-value for the Campaigns: 0.000} & \multicolumn{4}{|c|}{ P-value for the Rivers: 0.000} & & \\
\hline Campaign 1 & $\begin{array}{c}3.260 \pm \\
0.038\end{array}$ & $\begin{array}{c}3.074 \pm \\
0.861\end{array}$ & $\begin{array}{c}3.542 \pm \\
0.681\end{array}$ & $\begin{array}{c}3.071 \pm \\
0.281\end{array}$ & $\begin{array}{c}3.163 \pm \\
0.421\end{array}$ & $\begin{array}{c}3.111 \pm \\
0.612\end{array}$ & $\begin{array}{c}3.293 \pm \\
0.128\end{array}$ & $\begin{array}{c}3.179 \pm \\
0.116\end{array}$ & $\begin{array}{c}3.310 \pm \\
0.224\end{array}$ & $\begin{array}{c}3.223 \pm \\
0.374^{\mathrm{c}}\end{array}$ \\
\hline Campaign 2 & $\begin{array}{c}3.425 \pm \\
0.012\end{array}$ & $\begin{array}{c}3.286 \pm \\
0.682\end{array}$ & $\begin{array}{c}3.941 \pm \\
0.669\end{array}$ & $\begin{array}{c}3.189 \pm \\
0.324\end{array}$ & $\begin{array}{c}3.265 \pm \\
0.514\end{array}$ & $\begin{array}{c}3.269 \pm \\
0.671\end{array}$ & $\begin{array}{c}3.464 \pm \\
0.136\end{array}$ & $\begin{array}{c}3.328 \pm \\
0.311\end{array}$ & $\begin{array}{c}3.434 \pm \\
0.207\end{array}$ & $\begin{array}{c}3.400 \pm \\
0.392^{\mathrm{c}}\end{array}$ \\
\hline Campaign 3 & $\begin{array}{c}4.226 \pm \\
0.314\end{array}$ & $\begin{array}{c}4.195 \pm \\
0.868\end{array}$ & $\begin{array}{c}4.773 \pm \\
0.782\end{array}$ & $\begin{array}{c}4.123 \pm \\
0.364\end{array}$ & $\begin{array}{c}4.184 \pm \\
0.491\end{array}$ & $\begin{array}{c}4.248 \pm \\
0.910\end{array}$ & $\begin{array}{c}4.405 \pm \\
0.214\end{array}$ & $\begin{array}{c}4.141 \pm \\
0.361\end{array}$ & $\begin{array}{c}4.392 \pm \\
0.314\end{array}$ & $\begin{array}{c}4.299 \pm \\
0.513^{\mathrm{b}}\end{array}$ \\
\hline Campaign 4 & $\begin{array}{c}7.587 \pm \\
0.041\end{array}$ & $\begin{array}{c}7.268 \pm \\
0.328\end{array}$ & $\begin{array}{c}14.620 \pm \\
0.712\end{array}$ & $\begin{array}{c}6.306 \pm \\
0.417\end{array}$ & $\begin{array}{c}7.167 \pm \\
0.129\end{array}$ & $\begin{array}{c}7.401 \pm \\
0.221\end{array}$ & $\begin{array}{c}7.923 \pm \\
0.327\end{array}$ & $\begin{array}{c}7.007 \pm \\
0.110\end{array}$ & $\begin{array}{c}8.167 \pm \\
0.021\end{array}$ & $\begin{array}{c}8.161 \pm \\
0.256^{\mathrm{a}}\end{array}$ \\
\hline Mean & $\begin{array}{c}4.625 \pm \\
0.101^{\mathrm{b}}\end{array}$ & $\begin{array}{c}4.456 \pm \\
0.685^{\mathrm{b}}\end{array}$ & $\begin{array}{c}6.719 \pm \\
0.711^{\mathrm{a}}\end{array}$ & $\begin{array}{c}4.172 \pm \\
0.346^{\mathrm{b}}\end{array}$ & $\begin{array}{c}4.445 \pm \\
0.389^{\mathrm{b}}\end{array}$ & $\begin{array}{c}4.507 \pm \\
0.604^{\mathrm{b}}\end{array}$ & $\begin{array}{c}4.771 \pm \\
0.201^{\mathrm{b}}\end{array}$ & $\begin{array}{c}4.414 \pm \\
0.224^{\mathrm{b}}\end{array}$ & $\begin{array}{c}4.826 \pm \\
0.192^{\mathrm{b}}\end{array}$ & $\begin{array}{c}4.771 \pm \\
0.384\end{array}$ \\
\hline
\end{tabular}

Means with the same letters in the row or column are not statically different at significance level alpha = 0.05; Campaign 1: August 2016; Campaign 2: December 2016; Campaign 3: August 2016; Campaign 4: December 2017; $\mathrm{I}_{\mathrm{geo}}=$ Geoaccumulation index. 
Misisi, Makungu, Etó, Lubichako, Kacumvi, Kuwa, Mandje and Kimuti Rivers have been heavily to extremely polluted $\left(4<\mathrm{I}_{\text {geo }}<5\right)$. Similarly, the mean values of the geoaccumulation index of mercury in the sediments of the rivers studied also varied in a highly significant way from one investigation Campaign to another $(\mathrm{P}$-value $=0.000)$ while undergoing a high increase from Campaign 1 (August 2016) to Campaign 4 (December 2017). In fact, Campaign 4 (December 2017) presented the highest mean values of the mercury geoaccumulation index for all the sites studied $(9.688 \pm 0.256)$ followed in turn by Campaign 3 (August 2017) for which the mean values of the mercury geoaccumulation index were of the order of $4.415 \pm 0.513$; Campaign 2 (December 2016) $\left(\mathrm{I}_{\text {geo }}=3.530 \pm 0.392\right)$ and Campaign 1 (August 2016) $\left(\mathrm{I}_{\text {geo }}=3.305 \pm 0.374\right)$ for which the average values of the geoaccumulation index are statistically identical. Concerning the geoaccumulation index of mercury in sediments, Leila et al. (2014) as well as Manjunatha et al. (2001) also found that the sediments of the rivers of the Boumerzoug (Algeria) and Karwar (India) basins were extremely polluted by mercury. These researchers also found that the indices of geoaccumulation of mercury in sediments varied very significantly depending on the study campaigns.

\subsection{Mercury Contamination Factors for the Sediments Studied}

Results related to mercury contamination factors in different sediments studied are highlighted in Table 4.

The results reported in Table 4 show that the mean mercury contamination factor values in the sediments of the Etó, Misisi, Lubichako, Kimbi, Mandje, Kacumvi, Kimuti, Kuwa and Makungu Rivers were equal to $9.340 \pm 0.304$. In addition, the values of mercury contamination factors in the sediments of the rivers studied varied highly significantly from one site to another $(P$-value $=0.000)$.

Table 4. Mercury contamination factors for the sediments studied.

\begin{tabular}{|c|c|c|c|c|c|c|c|c|c|c|}
\hline $\begin{array}{c}\text { Rivers/ } \\
\text { Campaigns and } \\
\text { Parameter }\end{array}$ & Etó & Kacumvi & Kimbi & Kimuti & Kuwa & Lubichako & Makungu & Mandje & Misisi & Mean \\
\hline $\mathrm{CF}$ & \multicolumn{4}{|c|}{ P-value for the Campaigns: 0.000} & \multicolumn{4}{|c|}{ P-value for the Rivers: 0.000} & & \\
\hline Campaign 1 & $\begin{array}{c}3.750 \pm \\
0.418\end{array}$ & $\begin{array}{c}3.297 \pm \\
0.037\end{array}$ & $\begin{array}{c}4.606 \pm \\
0.512\end{array}$ & $\begin{array}{c}3.190 \pm \\
0.351\end{array}$ & $\begin{array}{c}3.162 \pm \\
0.195\end{array}$ & $\begin{array}{c}3.350 \pm \\
0.321\end{array}$ & $\begin{array}{c}3.863 \pm \\
0.214\end{array}$ & $\begin{array}{c}3.248 \pm \\
0.147\end{array}$ & $\begin{array}{c}3.873 \pm \\
0.293\end{array}$ & $\begin{array}{c}3.593 \pm \\
0.276^{\mathrm{d}}\end{array}$ \\
\hline Campaign 2 & $\begin{array}{c}5.333 \pm \\
0.486\end{array}$ & $\begin{array}{c}5.154 \pm \\
0.314\end{array}$ & $\begin{array}{c}5.744 \pm \\
0.891\end{array}$ & $\begin{array}{c}5.003 \pm \\
0.365\end{array}$ & $\begin{array}{c}5.163 \pm \\
0.199\end{array}$ & $\begin{array}{c}5.285 \pm \\
0.361\end{array}$ & $\begin{array}{c}5.312 \pm \\
0.317\end{array}$ & $\begin{array}{c}5.133 \pm \\
0.171\end{array}$ & $\begin{array}{c}5.312 \pm \\
0.342\end{array}$ & $\begin{array}{c}5.271 \pm \\
0.383^{\mathrm{c}}\end{array}$ \\
\hline Campaign 3 & $\begin{array}{c}13.150 \pm \\
0.467\end{array}$ & $\begin{array}{c}11.770 \pm \\
0.324\end{array}$ & $\begin{array}{c}18.381 \pm \\
0.247\end{array}$ & $\begin{array}{c}10.026 \pm \\
0.309\end{array}$ & $\begin{array}{c}10.840 \pm \\
0.020\end{array}$ & $\begin{array}{c}11.922 \pm \\
0.391\end{array}$ & $\begin{array}{c}14.072 \pm \\
0.025\end{array}$ & $\begin{array}{c}10.613 \pm \\
0.100\end{array}$ & $\begin{array}{c}14.178 \pm \\
0.423\end{array}$ & $\begin{array}{c}12.772 \pm \\
0.256^{\mathrm{b}}\end{array}$ \\
\hline Campaign 4 & $\begin{array}{c}15.281 \pm \\
0.496\end{array}$ & $\begin{array}{c}13.941 \pm \\
0.312\end{array}$ & $\begin{array}{c}28.222 \pm \\
0.012\end{array}$ & $\begin{array}{c}12.116 \pm \\
0.418\end{array}$ & $\begin{array}{c}13.056 \pm \\
0.143\end{array}$ & $\begin{array}{c}14.039 \pm \\
0.524\end{array}$ & $\begin{array}{c}15.976 \pm \\
0.162\end{array}$ & $\begin{array}{c}12.683 \pm \\
0.158\end{array}$ & $\begin{array}{c}16.209 \pm \\
0.472\end{array}$ & $\begin{array}{c}15.725 \pm \\
0.300^{\mathrm{a}}\end{array}$ \\
\hline Mean & $\begin{array}{c}9.378 \pm \\
0.467^{\mathrm{b}}\end{array}$ & $\begin{array}{c}8.541 \pm \\
0.247^{\mathrm{c}}\end{array}$ & $\begin{array}{c}14.238 \pm \\
0.416^{\mathrm{a}}\end{array}$ & $\begin{array}{c}7.584 \pm \\
0.361^{\mathrm{d}}\end{array}$ & $\begin{array}{c}8.055 \pm \\
0.139^{c}\end{array}$ & $\begin{array}{c}8.649 \pm \\
0.399^{c}\end{array}$ & $\begin{array}{c}9.806 \pm \\
0.180^{\mathrm{b}}\end{array}$ & $\begin{array}{c}7.920 \pm \\
0.144^{\mathrm{d}}\end{array}$ & $\begin{array}{c}9.893 \pm \\
0.382^{\mathrm{b}}\end{array}$ & $\begin{array}{c}9.340 \pm \\
0.304\end{array}$ \\
\hline
\end{tabular}

Means with the same letters in the row or column are not statically different at significance level alpha = 0.05; Campaign 1: August 2016; Campaign 2: December 2016; Campaign 3: August 2016; Campaign 4: December 2017; CF = Contamination factor. 
The Kimbi River sediments had the highest mean mercury contamination factor (CF) value compared to the mean values of mercury contamination factors in sediments of other rivers $(14.238 \pm 0.416)$, followed in turn by the sediments of the Misisi $(9.893 \pm 0.382)$, Makungu $(9.806 \pm 0.180)$ and Etó $(9.378 \pm 0.467)$ Rivers, whose mean values of mercury contamination factors are statistically equivalent; then Lubichako (8.649 \pm 0.399$)$, Kacumvi $(8.541 \pm 0.247)$ and Kuwa $(8.055 \pm 0.139)$ whose mean values of the mercury contamination factors are statistically similar; and finally Mandje (7.920 \pm 0.144$)$ and Kimuti $(7.584 \pm 0.361)$ whose mean values of the mercury contamination factors are statistically identical. Consistent with the mercury contamination gradient in the sediments of the rivers studied, it should be noted that the mercury contamination gradient was very strong in the sediments of all the rivers, including Etó, Misisi, Lubichako, Kimbi, Mandje, Kacumvi, Kimuti, Kuwa and Makungu $(6 \leq \mathrm{CF})$. In addition to this, the average values of mercury contamination factors in the sediments of the rivers studied also varied highly significantly from one survey Campaign to another $(\mathrm{P}$-value $=0.000)$ while undergoing huge increases from Campaign 1 (August 2016) to Campaign 4 (December 2017). Indeed, Campaign 4 (December 2017) presented the highest average values of mercury contamination factors for all sites studied $(18.720 \pm 0.300)$ followed respectively by Campaign 3 (August 2017) for which the average values of mercury contamination factors were of the order of 14,181 \pm 0.256 , from Campaign 2 (December 2016) for which the average values of the mercury contamination factors were equal to $5.386 \pm 0.383$ and finally from Campaign 1 (August 2016) for which the average values of the mercury contamination factors were of the order of $3.845 \pm 0.276$. Based on the mercury contamination factor, Manjunatha et al. (2001) as well as Banerjee et al. (2016) also found that the mercury contamination gradient was very strong in the sediments of the Indian rivers of the Karwar and Subarnarekha basin (India). These researchers also noted that the factors of mercury contamination in the sediments varied very significantly according to the study campaigns.

\subsection{Potential Ecological Risk Factor (PERF) for Mercury in the Sediments Studied}

The results for the potential ecological risk factors for mercury in the sediments studied are highlighted in Table 5.

In view of the results highlighted in Table 5, it can be seen that the average values of potential ecological risk factor related to mercury pollution in the sediments of the above-mentioned rivers were $194.900 \pm 0.371$. However, the potential ecological risk factor values related to mercurial pollution in the sediments of the rivers studied varied highly significantly from one river to another $(\mathrm{P}$-value $=0.000)$. For example, sediments from the Kimbi River had the highest average value of potential ecological risk factor compared to the average values of potential ecological risk factors for mercury pollution in the sediments of 
Table 5. Potential ecological risk factor for mercury in the sediments studied.

\begin{tabular}{|c|c|c|c|c|c|c|c|c|c|c|}
\hline $\begin{array}{c}\text { Rivers/ } \\
\text { Campaigns and } \\
\text { Parameter }\end{array}$ & Etó & Kacumvi & Kimbi & Kimuti & Kuwa & Lubichako & Makungu & Mandje & Misisi & Mean \\
\hline EPRF & & \multicolumn{3}{|c|}{ P-value for the Campaigns: 0.000} & \multicolumn{4}{|c|}{ P-value for the Rivers: 0.000} & & \\
\hline Campaign 1 & $\begin{array}{c}111.122 \pm \\
0.214\end{array}$ & $\begin{array}{c}96.443 \pm \\
0.240\end{array}$ & $\begin{array}{c}125.450 \pm \\
0.265\end{array}$ & $\begin{array}{c}85.915 \pm \\
0.260\end{array}$ & $\begin{array}{c}89.489 \pm \\
0.329\end{array}$ & $\begin{array}{c}97.912 \pm \\
0.920\end{array}$ & $\begin{array}{c}108.356 \pm \\
0.294\end{array}$ & $\begin{array}{c}87.203 \pm \\
0.210\end{array}$ & $\begin{array}{c}115.547 \pm \\
0.821\end{array}$ & $\begin{array}{c}101.937 \pm \\
0.395^{\mathrm{d}}\end{array}$ \\
\hline Campaign 2 & $\begin{array}{c}138.384 \pm \\
0.276\end{array}$ & $\begin{array}{c}115.013 \pm \\
0.120\end{array}$ & $\begin{array}{c}154.013 \pm \\
0.521\end{array}$ & $\begin{array}{c}97.188 \pm \\
0.260\end{array}$ & $\begin{array}{c}105.138 \pm \\
0.320\end{array}$ & $\begin{array}{c}116.765 \pm \\
0.900\end{array}$ & $\begin{array}{c}131.359 \pm \\
0.284\end{array}$ & $\begin{array}{c}101.089 \pm \\
0.210\end{array}$ & $\begin{array}{c}141.598 \pm \\
0.820\end{array}$ & $\begin{array}{c}122.283 \pm \\
0.413^{c}\end{array}$ \\
\hline Campaign 3 & $\begin{array}{c}195.889 \pm \\
0.264\end{array}$ & $\begin{array}{c}178.868 \pm \\
0.240\end{array}$ & $\begin{array}{c}312.103 \pm \\
0.127\end{array}$ & $\begin{array}{c}161.394 \pm \\
0.270\end{array}$ & $\begin{array}{c}168.387 \pm \\
0.014\end{array}$ & $\begin{array}{c}181.963 \pm \\
0.870\end{array}$ & $\begin{array}{c}192.484 \pm \\
0.271\end{array}$ & $\begin{array}{c}164.283 \pm \\
0.330\end{array}$ & $\begin{array}{c}201.528 \pm \\
0.862\end{array}$ & $\begin{array}{c}195.211 \pm \\
0.362^{\mathrm{b}}\end{array}$ \\
\hline Campaign 4 & $\begin{array}{c}336.288 \pm \\
0.612\end{array}$ & $\begin{array}{c}338.738 \pm \\
0.310\end{array}$ & $\begin{array}{c}418.542 \pm \\
0.387\end{array}$ & $\begin{array}{c}323.014 \pm \\
0.270\end{array}$ & $\begin{array}{c}350.530 \pm \\
0.027\end{array}$ & $\begin{array}{c}366.213 \pm \\
0.130\end{array}$ & $\begin{array}{c}377.819 \pm \\
0.262\end{array}$ & $\begin{array}{c}342.783 \pm \\
0.010\end{array}$ & $\begin{array}{c}387.573 \pm \\
0.815\end{array}$ & $\begin{array}{c}360.167 \pm \\
0.314^{\mathrm{a}}\end{array}$ \\
\hline Mean & $\begin{array}{c}195.421 \pm \\
0.342^{\mathrm{d}}\end{array}$ & $\begin{array}{c}182.265 \pm \\
0.230^{\mathrm{f}}\end{array}$ & $\begin{array}{c}252.527 \pm \\
0.325^{\mathrm{a}}\end{array}$ & $\begin{array}{c}166.878 \pm \\
0.270^{\mathrm{h}}\end{array}$ & $\begin{array}{c}178.386 \pm \\
0.172^{\mathrm{f}}\end{array}$ & $\begin{array}{c}190.713 \pm \\
0.710^{\mathrm{e}}\end{array}$ & $\begin{array}{c}202.505 \pm \\
0.278^{\mathrm{c}}\end{array}$ & $\begin{array}{c}173.840 \pm \\
0.190^{\mathrm{g}}\end{array}$ & $\begin{array}{c}211.561 \pm \\
0.830^{\mathrm{b}}\end{array}$ & $\begin{array}{c}194.900 \pm \\
0.371\end{array}$ \\
\hline
\end{tabular}

Means with the same letters in the row or column are not statically different at significance level alpha = 0.05; Campaign 1: August 2016; Campaign 2: December 2016; Campaign 3: August 2016; Campaign 4: December 2017; EPRF = Ecological Potential Risk Factor.

other rivers $(252.527 \pm 0.325)$, followed respectively by sediments from the Misisi River (211.561 \pm 0.830); Makungu (202.505 \pm 0.278); Etó (195.421 \pm 0.342$)$; Lubichako (190.713 \pm 0.706); then Kacumvi (182.265 \pm 0.232$)$ and Kuwa $(178.386 \pm 0.172)$ with statistically similar mean FREP values; Mandje (173.840 \pm $0.189)$; Kimuti $(166.878 \pm 0.266)$. In addition, the level of potential ecological risk from mercury pollution of sediments in all the rivers studied was high (160 $\leq$ PERF < 320). Similarly, the average values of the potential ecological risk factors relating to mercury pollution of the sediments of the rivers studied also varied in a highly significant manner from one investigation Campaign to another $(\mathrm{P}$-value $=0.000)$ while undergoing considerable increases from Campaign 1 (August 2016) to Campaign 4 (December 2017). Indeed, Campaign 4 (December 2017) presented the highest average values of potential ecological risk factors relating to mercury pollution for all the sites studied (375.639 \pm 0.314$)$, followed successively by Campaign 3 (August 2017) for which these values were of the order of $223.336 \pm 0.362$; Campaign 2 (December 2016) for which the mean PERF values were $130.921 \pm 0.413$ and finally Campaign 1 (August 2016) for which the mean FREP values were of the order of $108.283 \pm 0.395$. Based on the level of potential ecological risk of mercury pollution, Banu et al. (2013) and Banerjee et al. (2016) also noted that the level of potential ecological risk of mercury pollution of sediments in the Turag River (Bangladesh) and Subarnarekha River (India) was high. Moreover, these researchers also found that potential ecological risk factors related to mercury pollution of sediments in the rivers studied varied very significantly depending on the study campaigns.

\subsection{Ecological Risk Index for Mercury in the Sediments Studied}

Results that are consistent with the Ecological Risk Index for mercury in the sediments studied are reported in Table 6. 
Table 6. Ecological risk index for mercury in the sediments studied.

\begin{tabular}{|c|c|c|c|c|c|c|c|c|c|c|}
\hline $\begin{array}{c}\text { Rivers/ } \\
\text { Campaigns and } \\
\text { Parameter }\end{array}$ & Etó & Kacumvi & Kimbi & Kimuti & Kuwa & Lubichako & Makungu & Mandje & Misisi & Mean \\
\hline ERI & & \multicolumn{3}{|c|}{ P-value for the Campaigns: 0.000} & \multicolumn{4}{|c|}{ P-value for the Rivers: 0.000} & & \\
\hline Campaign 1 & $\begin{array}{c}432.725 \pm \\
0.800\end{array}$ & $\begin{array}{c}421.895 \pm \\
0.480\end{array}$ & $\begin{array}{c}507.137 \pm \\
0.520\end{array}$ & $\begin{array}{c}359.742 \pm \\
0.630\end{array}$ & $\begin{array}{c}396.833 \pm \\
0.710\end{array}$ & $\begin{array}{c}414.703 \pm \\
0.550\end{array}$ & $\begin{array}{c}444.091 \pm \\
0.530\end{array}$ & $\begin{array}{c}417.477 \pm \\
0.450\end{array}$ & $\begin{array}{c}436.241 \pm \\
0.590\end{array}$ & $\begin{array}{c}425.649 \pm \\
0.580^{\mathrm{d}}\end{array}$ \\
\hline Campaign 2 & $\begin{array}{c}502.907 \pm \\
0.820\end{array}$ & $\begin{array}{c}490.336 \pm \\
0.480\end{array}$ & $\begin{array}{c}588.935 \pm \\
0.150\end{array}$ & $\begin{array}{c}438.293 \pm \\
0.610\end{array}$ & $\begin{array}{c}468.783 \pm \\
0.620\end{array}$ & $\begin{array}{c}510.961 \pm \\
0.410\end{array}$ & $\begin{array}{c}513.581 \pm \\
0.370\end{array}$ & $\begin{array}{c}413.231 \pm \\
0.360\end{array}$ & $\begin{array}{c}525.109 \pm \\
0.160\end{array}$ & $\begin{array}{c}494.682 \pm \\
0.440^{c}\end{array}$ \\
\hline Campaign 3 & $\begin{array}{c}615.184 \pm \\
0.870\end{array}$ & $\begin{array}{c}604.061 \pm \\
0.460\end{array}$ & $\begin{array}{c}621.888 \pm \\
0.050\end{array}$ & $\begin{array}{c}602.000 \pm \\
0.590\end{array}$ & $\begin{array}{c}604.493 \pm \\
0.630\end{array}$ & $\begin{array}{c}609.132 \pm \\
0.570\end{array}$ & $\begin{array}{c}622.819 \pm \\
0.320\end{array}$ & $\begin{array}{c}603.758 \pm \\
0.410\end{array}$ & $\begin{array}{c}625.742 \pm \\
0.140\end{array}$ & $\begin{array}{c}612.120 \pm \\
0.450^{\mathrm{b}}\end{array}$ \\
\hline Campaign 4 & $\begin{array}{c}627.483 \pm \\
0.840\end{array}$ & $\begin{array}{c}618.059 \pm \\
0.420\end{array}$ & $\begin{array}{c}643.777 \pm \\
0.850\end{array}$ & $\begin{array}{c}610.727 \pm \\
0.240\end{array}$ & $\begin{array}{c}615.528 \pm \\
0.612\end{array}$ & $\begin{array}{c}626.438 \pm \\
0.650\end{array}$ & $\begin{array}{c}634.084 \pm \\
0.350\end{array}$ & $\begin{array}{c}617.649 \pm \\
0.430\end{array}$ & $\begin{array}{c}637.078 \pm \\
0.440\end{array}$ & $\begin{array}{c}625.647 \pm \\
0.540^{\mathrm{a}}\end{array}$ \\
\hline Mean & $\begin{array}{c}544.575 \pm \\
0.830^{\mathrm{c}}\end{array}$ & $\begin{array}{c}533.588 \pm \\
0.461^{\mathrm{e}}\end{array}$ & $\begin{array}{c}590.434 \pm \\
0.390^{\mathrm{a}}\end{array}$ & $\begin{array}{c}502.690 \pm \\
0.520^{\mathrm{g}}\end{array}$ & $\begin{array}{c}521.410 \pm \\
0.640^{\mathrm{e}}\end{array}$ & $\begin{array}{c}540.308 \pm \\
0.550^{\mathrm{d}}\end{array}$ & $\begin{array}{c}553.644 \pm \\
0.390^{\mathrm{b}}\end{array}$ & $\begin{array}{c}513.029 \pm \\
0.411^{\mathrm{f}}\end{array}$ & $\begin{array}{c}556.042 \pm \\
0.330^{\mathrm{b}}\end{array}$ & $\begin{array}{c}539.524 \pm \\
0.500\end{array}$ \\
\hline
\end{tabular}

Means with the same letters in the row or column are not statically different at significance level alpha $=0.05$; Campaign 1: August 2016; Campaign 2: December 2016; Campaign 3: August 2016; Campaign 4: December 2017; ERI = Ecological risk index.

Based on the results presented in Table 6, it can be seen that the average values of the ecological risk index in relation to mercury pollution in the sediments of the rivers studied were of the order of $539.524 \pm 0.503$. Nevertheless, the various values of the ecological risk index (ERI) related to mercury pollution in the sediments of the rivers studied varied in a highly significant way from one river to another $(\mathrm{P}$-value $=0.000)$.

Thus, the sediments of the Kimbi River had the highest mean value of the ecological risk index for mercury pollution compared to the mean values of the ecological risk indices for mercury pollution of sediments of other rivers (590.434 \pm $0.392)$ followed alternately by the sediments of the Misisi (556.042 \pm 0.332$)$ and Makungu (553.644 \pm 0.391$)$ Rivers, whose mean values of the ecological risk indices are statistically similar; Etó (544.575 \pm 0.832$)$; Lubichako (540.308 \pm 0.546$)$; then Kacumvi $(533.588 \pm 0.461)$ and Kuwa $(521.410 \pm 0.644)$ with statistically similar mean values of ecological risk index; Mandje (513.029 \pm 0.411 ); Kimuti $(502.690 \pm 0.516)$. Based on the average values of the ecological risk index, it was found that the level of ecological risk in relation to mercury pollution of sediments in all the rivers studied (Makungu, Kuwa, Kimbi, Misisi, Kimuti, Kacumvi, Etó, Mandje and Kuwa) was considerable $(300 \leq$ ERI < 600). Similarly, the average values of the ecological risk index relating to mercury pollution of the sediments of the rivers studied varied in a highly significant way from one investigation Campaign to another ( $\mathrm{P}$-value $=0.000)$ while increasing significantly from Campaign 1 (August 2016) to Campaign 4 (December 2017).

In fact, Campaign 4 (December 2017) presented the highest average values of ecological risk index for mercury pollution for all the sites studied (630.598 \pm 0.535) followed in turn by Campaign 3 (August 2017) for which these values were of the order of $615.131 \pm 0.449$ from Campaign 2 (December 2016) for which the 
average values of the ecological risk indices were equal to $517.145 \pm 0.442$ and finally from Campaign 1 (August 2016) for which the average values of the ecological risk index were equal to $446.050 \pm 0.585$. Based on the mean values of the ecological risk index, Banu et al. (2013) and Leila et al. (2014) also found that the level of ecological risk related to mercury pollution of the sediments of the Turag River (Bangladesh) and those of the Boumerzoug Basin (Algeria) was considerable. In addition to this, these researchers have also observed that the ecological risk index related to mercury pollution of sediments in the rivers studied vary very significantly depending on the study campaigns.

\section{Conclusion}

The sediments of the rivers that drain the gold panning sites in the Fizi territory are amply polluted by mercury in relation to their total mercury content and the values of their mercury pollution index, in this case the mercury enrichment factor, the mercury contamination factor, the mercury geoaccumulation Index, the mercury potential ecological risk factor and the ecological risk index that deviate from the standards recommended by the Canadian Council of Ministers of the Environment. Faced with this high level of mercury pollution in the sediments studied, it is necessary to consider the best solutions likely to protect the aquatic ecosystems of the gold panning sites in the Fizi territory. Thus, it would be advisable to regularly reinforce the capacity of gold panners by organizing workshops for their attention, focusing mainly on the mercury pollution of aquatic ecosystems, the importance of recycling gold panning effluents before discharging them into waterways, etc. Further research on this topic will focus respectively on the identification of mercury-resistant bacteria communities in the sediments studied and on the in vitro study of the effects of these sediments on fish.

\section{Conflicts of Interest}

The authors declare no conflicts of interest regarding the publication of this paper.

\section{References}

Banerjee, S., Kumar, A., \& Maiti, S. K. (2016). Seasonal Variation in Heavy Metal Contaminations in Water and Sediments of Jamshedpur Stretch of Subarnarekha River, India. Environmental Earth Sciences, 75, 1-12. https://doi.org/10.1007/s12665-015-4990-6

Banu, Z., Chowdhury, M., \& Hossain, D. M. (2013). Contamination and Ecological Risk Assessment of Heavy Metal in the Sediment of Turag River, Bangladesh: An Index Analysis Approach. Journal of Water Resource and Protection, 5, 239-247. https://doi.org/10.4236/jwarp.2013.52024

Bhuiyan, M. A., Parvez, L., \& Islam, M. A. (2010). Heavy Metal Pollution of Coal Mine-Affected Agricultural Soils in the Northern Part of Bangladesh. Journal of Hazardous Materials, 173, 384-392. https://doi.org/10.1016/j.jhazmat.2009.08.085

Chouti, W., Mama, D., Changotade, O., Alapini, F., \& Boukari, M. (2010). Étude des élé- 
ments traces métalliques contenus dans les sédiments de la lagune de Porto-Novo (Sud Bénin). Journal of Applied Biosciences, 34, 2186-2197.

Delphine, F. (2002). Géochimie du mercure dans des sédiments estuariens et côtiers: Cas de la Seine (France) et de la baie de Kaštela (Croatie) (180 p.). Thèse de doctorat, Villeneuve-d'Ascq: Université des Sciences et Technologies de Lille.

Gerardo, M., Stephen, A. M., Charles, T. D., Svetoslava, T., Steven, W., Julio, F. A., Claudia, M. V., \& Luis, E. F. (2018). Mercury Contamination in Riverine Sediments and Fish Associated with Artisanal and Small-Scale Gold Mining in Madre de Dios, Peru. International Journal of Environmental Research and Public Health, 15, 1584-1599. https://doi.org/10.3390/ijerph15081584

Kennish, M. J. (2002). Environmental Threats and Environmental Future of Estuaries. Environmental Conservation, 29, 78-107. https://doi.org/10.1017/S0376892902000061

Leila, S., Mohamed, E. H., Fatima, Z. A., \& Smail, M. (2014). Utilisation d'indices pour l'évaluation de la qualité des sédiments: Cas du bassin Boumerzoug (Algérie). European Scientific Journal, 10, 336-346.

Manjunatha, B. R., Balakrishna, K., Shankar, R., \& Mahalingam, T. R. (2001). Geochemistry and Assessment of Metal Pollution in Soils and River Components of a Monsoon-Dominated Environment near Karwar, Southwest Coast of India. Environmental Geology, 40, 1462-1470. https://doi.org/10.1007/s002540100342

Marie, L. C. (2012). Caractérisation physico-chimique d'un sédiment marin traité aux liants hydrauliques: Évaluation de la mobilité potentielle des polluants inorganiques (230 p.). Thèse de doctorat, Lyon: Inst. National des Sciences Appliquées de Lyon.

Munyaas, W. N. (2016). Territoire de Fizi-Kalembelembe, défis et développement (80 p.). Paris: Ed. Persée.

Niane, B. (2014). Impacts environnementaux liés à l'utilisation du mercure lors de l'exploitation artisanale de l'or dans la région de Kédougou (Sénégal oriental). Thèse de doctorat, Genève: Université de Genève.

Noah, K. A., \& Anthony, A. (2016). Influence of Mining Related Activities on Levels of Mercury in Water, Sediment and Fish from the Ankobra and Tano River Basins in South Western Ghana. Environmental Systems Research, 5, 1-17. https://doi.org/10.1186/s40068-016-0055-4

Pestana, M. H., Lechler, P., \& Formoso, M. L. (2010). Mercury in Sediments from Gold and Copper Exploitation Areas in the Camaqua River Basin, Southern Brazil. Journal of South American Earth Sciences, 13, 537-547. https://doi.org/10.1016/S0895-9811(00)00039-0

Poulton, S. W., \& Raiswel, R. (2000). Solid Phase Associations, Oceanic Fluxes and the Anthropogenic Perturbation of Transition Metals in World River Particulates. Marine Chemistry, 72, 17-31. https://doi.org/10.1016/S0304-4203(00)00060-8

Tessier, E. (2012). Diagnostic de la contamination sédimentaire par les métaux/metallö̈des dans la Rade de Toulon et mécanismes contrôlant leur mobilité (200 p.). Thèse de doctorat, Var: Université du Sud Toulon.

Wang, S., Jia, Y., Wang, X., Wang, H., Zhao, Z., \& Liu, B. (2009). Total Mercury and Monomethylmercury in Water, Sediments and Hydrophytes from the Rivers, Estuary, and Bay along the Bohai Sea Coast, Northeastern China. Applied Geochemistry, 24, 1702-1711. https://doi.org/10.1016/j.apgeochem.2009.04.037 